\title{
Full-depth zooplankton profiles over the deep bathyal of the NE Atlantic*
}

\author{
Rolf Koppelmann, Horst Weikert
}

Institut für Hydrobiologie und Fischereiwissenschaft, Zeiseweg 9, W-2000 Hamburg 50, Germany

\begin{abstract}
Vertical profiles of zooplankton (size range less than $5 \mathrm{~mm}$ ) were taken with a $1 \mathrm{~m}^{2}$ MOCNESS ( $333 \mu \mathrm{m}$ mesh aperture) from the $>4000 \mathrm{~m}$ water column at 2 sites in the NE Atlantic. In the upper $1000 \mathrm{~m}$, the profiles tended to exhibit high variability and were influenced by diurnal migrations but below, the distributions were nearly similar. The standing crop in the upper $400 \mathrm{~m}$ was remarkably low, possibly due to a bloom of salps and their grazing pressure on the phytoplankton crop. The nonlinear decrease of the normalized zooplankton abundance and biomass below $1000 \mathrm{~m}$ in the area investigated could be approximated by a power function. The improved regression 'model' revealed no differences between the slopes when compared to biomass data from other marine locations given by various authors. This indicates that the processes of vertical material flux seem to be similar in many bathypelagic systems of the open sea. The $y$-intercepts, however, showed differences due to either a higher surface productivity in some ocean areas or differences in sampling methods and evaluation of the material. Possible causes which may have led to less of a decrease in zooplankton abundance at greater depths (below $2500 \mathrm{~m}$ ) such as food supply, resuspension, upward flux, faunal changes and trophic interactions are discussed.
\end{abstract}

\section{INTRODUCTION}

In the course of the BIOTRANS programme (Pfannkuche et al. 1990) 2 deep sites in the temperate NE Atlantic were investigated. Special attention was given to small-scale zooplankton distribution below the epipelagic zone. Only a few papers from the NE Atlantic (Angel \& Baker 1982, Roe 1988, Roe et al. 1990), the Mediterranean Sea (Weikert 1990, Weikert \& Trinkaus 1990) and the Red Sea (Weikert 1982) present quantitative studies below $1500 \mathrm{~m}$ at depth sampling intervals $\leq 500 \mathrm{~m}$. Quantitative data from below $6000 \mathrm{~m}$ are still rare and generally based on relatively coarse 1000 to $2000 \mathrm{~m}$ sample steps (see Vinogradov 1968, Vinogradov \& Tseitlin 1983 and literature quoted therein).

The aim of this paper is to present data on the bathymetric distribution of zooplankton and zooplankton standing crops over a depth of $4500 \mathrm{~m}$ and to compare these 'fine'-scaled data with those from previous studies at greater depths. The distribution of the zooplankton in the bathypelagic zone is discussed with a view to its description by 2 regression 'models'. Data on the distribution of specific taxa which are involved will be published elsewhere.

\footnotetext{
- BIOTRANS publication no. 25
}

\section{MATERIALS AND METHODS}

Zooplankton was sampled throughout the water column during Cruise 06, Leg $7 \mathrm{~A} / \mathrm{B}$, of the RV 'Meteor' at 2 deep oceanic sites in the NE Atlantic: the BIOTRANS area (between $47^{\circ} \mathrm{N}, 19^{\circ} \mathrm{W}$ and $47^{\circ} 30^{\prime} \mathrm{N}, 20^{\circ} \mathrm{W}$; Pfannkuche et al. 1990) and the European Community (EC) station northeast of the BIOTRANS area at $48^{\circ} 50^{\prime} \mathrm{N}, 16^{\circ} 30^{\prime} \mathrm{W}$ (Fig. 1). The hydrography of the BIOTRANS area was well explored during the NOAMP project (Northeast Atlantic Monitoring Program; Mittelstaedt et al. 1986). Typical for the deep open sea, it exhibits a stable hydrographic environment. Different types of water masses were identified by CTD measurements: surface water from 0 to $150 \mathrm{~m}$, North Atlantic Central water between 150 and $650 \mathrm{~m}$, Mediterranean water between 650 and $1250 \mathrm{~m}$, Labrador water from 1700 to $2000 \mathrm{~m}$, Middle North Atlantic Deep water between 2300 and $2800 \mathrm{~m}$, and bottom water below $4000 \mathrm{~m}$.

Stratified oblique tows were carried out with a $1 \mathrm{~m}^{2}$ MOCNESS (multiple opening/closing net and environmental sensing system; Wiebe et al. 1985) at standard depth intervals (Table 1). The MOCNESS was equipped with 9 black nets, which could be opened and closed sequentially at discrete depths. The $333 \mu \mathrm{m}$ mesh nets are not expected to collect animals smaller 


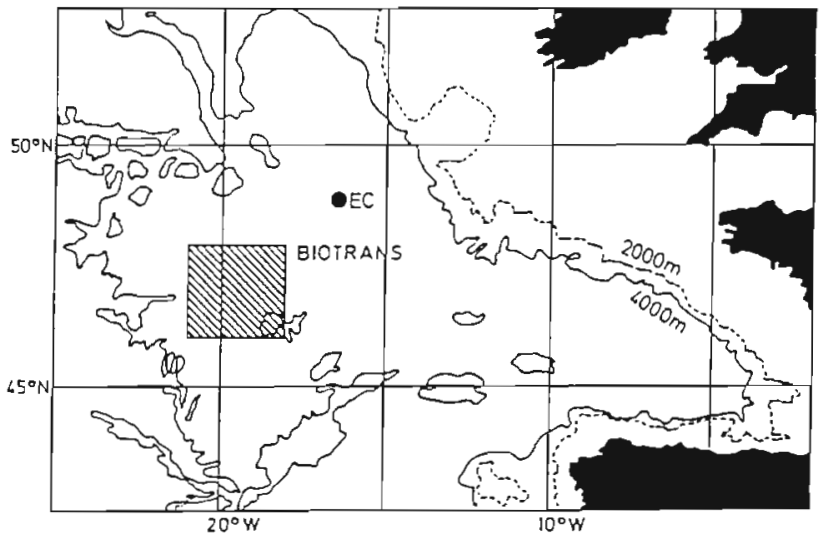

Fig. 1. Sampling sites in the NE Atlantic

than $1 \mathrm{~mm}$ quantitatively (e.g. Barnes \& Tranter 1965 , Böttger 1987). The water volume filtered was estimated by a calibrated flowmeter and corrected for the net frame angle and the angle of the oblique haul through the water. The flowmeter failed in 3 tows (marked with an asterisk in Table 2). For these tows the volume of water filtered was estimated by a geometric formula (Beckmann 1988). The mean filtered volumes and their

Table 1. Standard sampling intervals in the water column and the mean filtered volumes. SD: standard deviation; n: no. of samples

\begin{tabular}{|ccccc|}
\hline $\begin{array}{l}\text { Strata } \\
(\mathrm{m})\end{array}$ & $\begin{array}{c}\text { Sample } \\
\text { intervals }(\mathrm{m})\end{array}$ & $\begin{array}{c}\text { Mean filtered } \\
\text { volume }\left(\mathrm{m}^{3}\right)\end{array}$ & SD & $\mathrm{n}$ \\
\hline $0-450$ & 50 & 350 & 185 & 24 \\
$450-1050$ & 150 & 1100 & 360 & 16 \\
$1050-2250$ & 200 & 1370 & 526 & 21 \\
$2250-3000$ & 250 & 1930 & 425 & 11 \\
$3000-5000$ & 250 or 500 & 2270 & 981 & 11 \\
\hline
\end{tabular}

standard deviation of each fishing stratum are shown in Table 1.

Table 2 summarizes the sampling time and procedures at the 2 sites. In the BIOTRANS area (water depth ca $4500 \mathrm{~m}$ ), a day profile was taken from the surface to $3300 \mathrm{~m}$; at night, 1 profile was taken from 10 $\mathrm{m}$ to $4460 \mathrm{~m}$ and a second one from $400 \mathrm{~m}$ to $1650 \mathrm{~m}$. From the EC station (water depth ca $4800 \mathrm{~m}$ ), a day profile was available from $150 \mathrm{~m}$ to $4000 \mathrm{~m}$. Due to large sampling times, the profiles were composed of shorter profiles from different days. Day and night differences can be disregarded below $700 \mathrm{~m}$ (Angel 1979) and $1000 \mathrm{~m}$, respectively (Angel et al. 1982, Longhurst et al. 1989). In our data, there was also no difference evident between the day profiles below 1000 $m$ in the BIOTRANS area and the EC station. Therefore, these data from both sites were combined into a single profile (see Fig. $2 b, c$ ).

The plankton samples were preserved in a $4 \%$ seawater-formaldehyde solution buffered with hexamethylenetetramine. The material was sorted in a fluid composed of $0.5 \%$ propylene phenoxetol, $5 \%$ propylene glycol and 94.5\% tap water (Steedman 1976).

The metazoa of the mesozooplankton (upper threshold length $5 \mathrm{~mm}$; see Weikert \& Trinkaus 1990) were wet weighed after Tranter (1962). This method allows the subsequent specific analysis of the bathypelagic samples, which were too small in order to make aliquots for a more precise dry weight or carbon determination. Large samples from the upper $1000 \mathrm{~m}$ were split by a whirling vessel (Wiborg 1951) into fractions of tenths or hundredths before being sorted. Exoskeletons and carcasses, excluded from the counts, were discriminated according to Wheeler (1967) and Weikert (1977) together with large-sized flocculent material. The composition of this material (phytoplankton, faeces, radiolaria) was similar to that described for the same area from the sea-bottom (see Thiel et al. 1988/

Table 2. Station data. B: BIOTRANS-area; EC: European Community station; (D): Dayhaul; (N): Nighthaul

\begin{tabular}{|c|c|c|c|c|}
\hline Haul & Date & Local time & Area & Depth range $(\mathrm{m})$ \\
\hline MOC -13 & 11 Apr 88 & $00: 40-01: 22(\mathrm{~N})$ & $\mathrm{B}$ & $1650-3600$ \\
\hline MOC -14 & 11 Apr 88 & $13: 41-17: 45$ (D) & $B$ & $1450-3300$ \\
\hline MOC- 15 & $13 \mathrm{Apr} 88$ & $21: 32-23: 49(N)$ & $\mathrm{B}$ & $400-1650$ \\
\hline MOC-16 & 14 Apr 88 & $02: 57-03: 50(\mathrm{~N})$ & $\mathrm{B}$ & $10-400$ \\
\hline $\mathrm{MOC}-17$ & 17 Apr 88 & $00: 48-02: 50(\mathrm{~N})$ & $\mathrm{B}$ & $400-1650$ \\
\hline $\mathrm{MOC}-18$ & 17 Apr 88 & $11: 18-14: 09$ (D) & $B$ & $400-1650$ \\
\hline $\mathrm{MOC}-20^{\circ}$ & 22 Apr 88 & $13: 48-14: 31$ (D) & $\mathrm{B}$ & $0-450$ \\
\hline MOC $-21^{\circ}$ & 4 May 88 & $10: 18-14: 30$ (D) & $\mathrm{EC}$ & $1850-4000$ \\
\hline $\mathrm{MOC}-22^{\circ}$ & 5 May 88 & $12: 55-15: 35$ (D) & $\mathrm{EC}$ & $400-1650$ \\
\hline $\mathrm{MOC}-23$ & 6 May 88 & $14: 00-14: 32$ (D) & $\mathrm{EC}$ & $150-450$ \\
\hline $\mathrm{MOC}-24$ & 10 May 88 & $00: 08-04: 23(N)$ & $\mathrm{B}$ & $2750-4460$ \\
\hline
\end{tabular}


1989). The formation of our material during a bioom of phytoplankton and salps justifies use of the term phytodetritus (Billett et al. 1983, Rice et al. 1986, Thiel et al. 1988/1989). The wet weight of this material was estimated as described above and subtracted from the zooplankton biomass.

The phytodetritus and zooplankton biomass and the animal counts were standardized to a per $1000 \mathrm{~m}^{3}$ basis and plotted on a logarithmic scale with depth. The mean values and their ranges, if available, are presented at the midpoints of the sampled depth intervals.

\section{RESULTS}

\section{Total zooplankton and biomass}

In the BIOTRANS area, zooplankton was concentrated during the day in the upper $50 \mathrm{~m}$ (ca 80000 ind. $1000 \mathrm{~m}^{-3}$; Fig. 2a). Numbers decreased to ca 22500 ind. $1000 \mathrm{~m}^{-3}$ at a depth of $200 \mathrm{~m}$, and then increased again to a maximum of more than 90000 ind. $1000 \mathrm{~m}^{-3}$ at $350-400 \mathrm{~m}$. Below $400 \mathrm{~m}$ there was a fairly steady decrease in numbers down to $1000 \mathrm{~m}$ (2000 ind. 1000 $\left.\mathrm{m}^{-3}\right)$.

The day profile from the EC station commenced at $150 \mathrm{~m}$. The depth-related decrease of zooplankton was more gradual than in the BIOTRANS area. The maximum value in the mesopelagic zone was moderate (ca 55000 ind. $1000 \mathrm{~m}^{-3}$ ) and was recorded at $200-300 \mathrm{~m}$

The night profile in the BIOTRANS area exhibited the highest concentration in the upper $50 \mathrm{~m}$ (ca 280000 ind. $1000 \mathrm{~m}^{-3}$ ), which was followed by a rapid decrease to 35000 ind. $1000 \mathrm{~m}^{-3}$ between $100 \mathrm{~m}$ and $150 \mathrm{~m}$. Below $150 \mathrm{~m}$ the gradient was similar to that of the day profiles. Around $450 \mathrm{~m}$, a small secondary maximum of nearly 33000 ind. $1000 \mathrm{~m}^{-3}$ was detected.

In the bathypelagic zone, i.e. below $1000 \mathrm{~m}$, the individual concentration by day and night decreased drastically from 4000 ind. $1000 \mathrm{~m}^{-3}$ at $1000 \mathrm{~m}$ to 200 ind. $1000 \mathrm{~m}^{-3}$ at $4500 \mathrm{~m}$ (Fig. 2b). Irrespective of the time of day there was a distinct increase in abundance at $2750-3000 \mathrm{~m}$ in all profiles. The mean of 500 ind. $1000 \mathrm{~m}^{-3}$ at this depth exceeded the value for the overlying $2500-2750 \mathrm{~m}$ sample interval by $230 \%$.

Zooplankton biomass could not be estimated for all sampling intervals due to methodology. However, a single mean profile, composed of BIOTRANS day data and, below $1000 \mathrm{~m}$, additional data from the EC day station and the BIOTRANS night profile (Fig. 2c), is available to show the sequence of biomass decrease with depth.

In the upper $100 \mathrm{~m}$, the biomass was ca $8900 \mathrm{mg} 1000$ $\mathrm{m}^{-3}$ wet weight and decreased to $2400 \mathrm{mg} 1000 \mathrm{~m}^{-3}$ at $200 \mathrm{~m}$ depth. The principal biomass maximum of
$16800 \mathrm{mg} 1000 \mathrm{~m}^{-3}$ occurred between 300 and $500 \mathrm{~m}$. Within the subsequent $200 \mathrm{~m}$, the biomass decreased sharply to $1200 \mathrm{mg} 1000 \mathrm{~m}^{-3}$ at $700 \mathrm{~m}$. Below $700 \mathrm{~m}$, the decline became less with depth reaching a minimum of $100 \mathrm{mg} 1000 \mathrm{~m}^{-3}$.

\section{DISCUSSION}

\section{Zooplankton standing crop}

Biomass data from the NE Atlantic over the $4000 \mathrm{~m}$ water column are sparse, and published fine-scaled individual data do not exist. Our total biomass crop compares fairly well with Roe's (1988) dry weight data (320 $\mu \mathrm{m}$ mesh size), which was converted (conversion factor 1:5) into wet weight after Cushing et al. (1958), from an oligotrophic region (Madeira Abyssal Plain: $7500 \mathrm{mg} \mathrm{m}^{-2}$; this study $6700 \mathrm{mg} \mathrm{m}^{-2}$ ). Most of the zooplankton biomass $(74 \%)$ was distributed in the upper $1000 \mathrm{~m}$. Angel \& Baker (1982) yielded a similar ratio of some $75 \%$ from the upper $900 \mathrm{~m}$ in the NE Atlantic (330 $\mu \mathrm{m}$ mesh size).

Ninety percent of the individual crop was collected in the upper $1000 \mathrm{~m}$. However, as exemplified by the BIOTRANS day station, the standing crop of counts was remarkably low in the upper $400 \mathrm{~m}$ (17300 ind. $\mathrm{m}^{-2}$ of total zooplankton; 13960 ind. $\mathrm{m}^{-2}$ of copepods) as compared with data from other Atlantic regions (Table 3). This may in part be explained by the fact that in our study, only metazoans smaller than $5 \mathrm{~mm}$ were considered. However, this methodological difference should only affect calculations of the total zooplankton crop, not the copepod crop because the copepod fraction $>5 \mathrm{~mm}$ was negligibly small in numbers. In an adjacent area at $48^{\circ} \mathrm{N}, 21^{\circ} \mathrm{W}$, Beckmann et al. (1987) using a $300 \mu \mathrm{m}$ mesh size (multiple closing net; Weikert \& John 1981), reported 41400 to 50700 ind. $\mathrm{m}^{-2}$ (total zooplankton) from the upper $400 \mathrm{~m}$ of a cold-core eddy. This concentration is higher by a factor of 3 than that in our study. Higher values were also found by Colman (1962) in the Bay of Biscay of the NE Atlantic (55260 ind. $\mathrm{m}^{-2}$ of total zooplankton and 42280 ind. $\mathrm{m}^{-2}$ of copepods in the upper $500 \mathrm{~m}$ ) from catches with a 230 $\mu \mathrm{m}$ net. Even in the oligotrophic waters of the Sargasso Sea higher crops were found. Deevey \& Brooks (1977) reported some 80000 copepods $\mathrm{m}^{-2}$ in the upper $500 \mathrm{~m}$ of the oligotrophic Sargasso Sea using a $202 \mu \mathrm{m}$ mesh, while the crop of the larger $363 \mu \mathrm{m}$ net zooplankton equalled our estimate.

The low mesozooplankton abundances in our study were associated with a mass occurrence of salps (predominantly Salpa fusiformis) in the fraction larger than $5 \mathrm{~mm}$ (2130 ind $\mathrm{m}^{-2}$ during daytime and 730 ind. $\mathrm{m}^{-2}$ 
during the night in the upper $400 \mathrm{~m}$ ). Salps are capable of ingesting particles as small as $1 \mathrm{~mm}$ (Harbison \& Gilmer 1976). They can reduce the phytoplankton stock markedly (Deibel 1982), thus affecting the stock of other, mainly crustacean, zooplankton by competition (Berner 1957, 1967 as quoted by Silver \& Bruland 1981). At the BIOTRANS site, high production rates of phytoplankton were found at the same time. Because of the grazing pressure exerted by the salps, the high production rate did not result in a high phytoplankton stock (Stienen et al. 1988). Pfannkuche et al. (1988) found fecal pellets of salps together with phytodetritus at the sea floor of the BIOTRANS area. This indicates that grazing of phytoplankton by salps had commenced some time before our study.
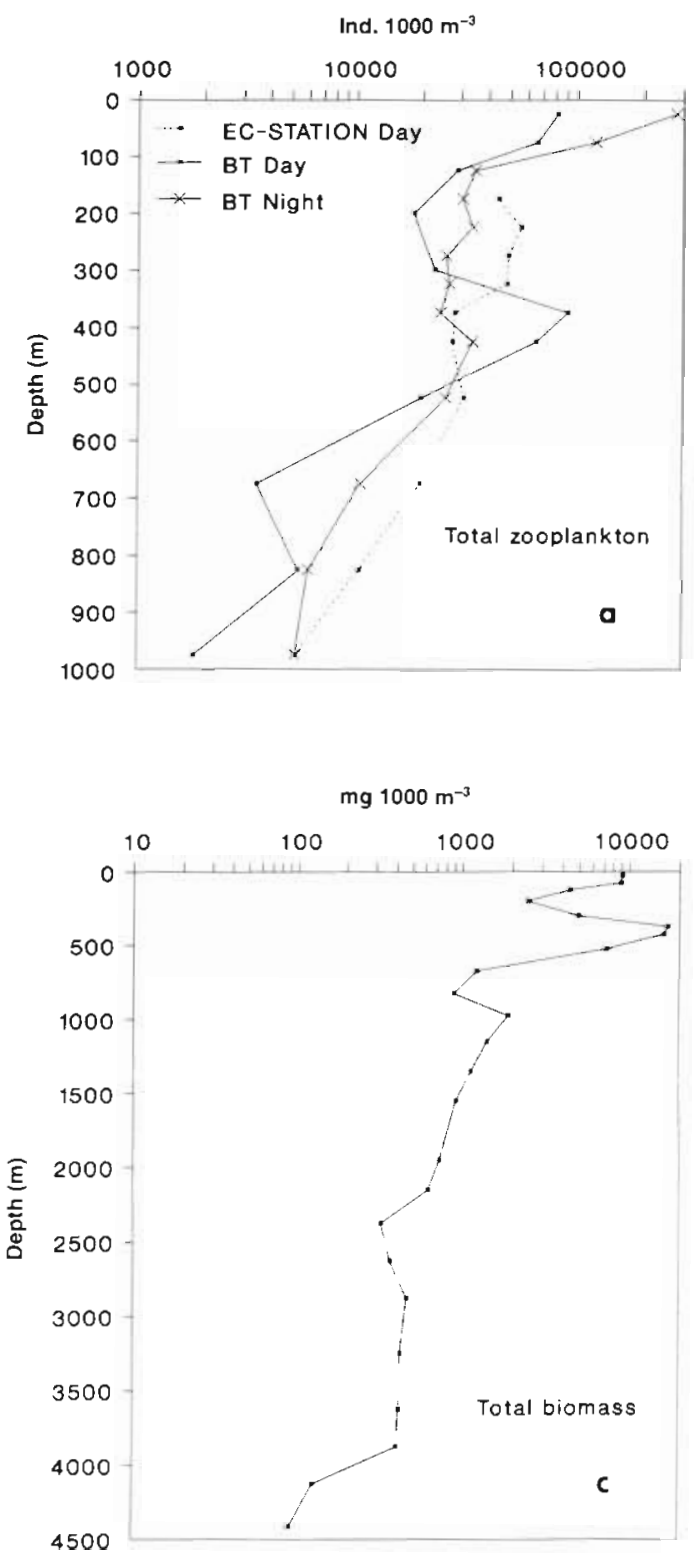

\section{Gross vertical distribution of total zooplankton}

Overall, the distribution of zooplankton numbers and biomass at the studied sites was similar to the biomass profiles published by Angel \& Baker (1982) from 3 sites in the NE Atlantic. Especially notable is the increase of individuals in the bathypelagic zone at $2750-3000 \mathrm{~m}$ by an order of magnitude compared to the contiguous depth intervals (2500-2750 $\mathrm{m}$ and $3000-3500 \mathrm{~m}$, respectively). Angel \& Baker (1982) found an increase in biomass at similar depths at their $42^{\circ} \mathrm{N}$ station, but this increase was not detected at their station at $49^{\circ} \mathrm{N}$. This may be due to the large sampling intervals of 500 $m$ at the latter location which may have blurred the difference. The increase of individuals in our samples,

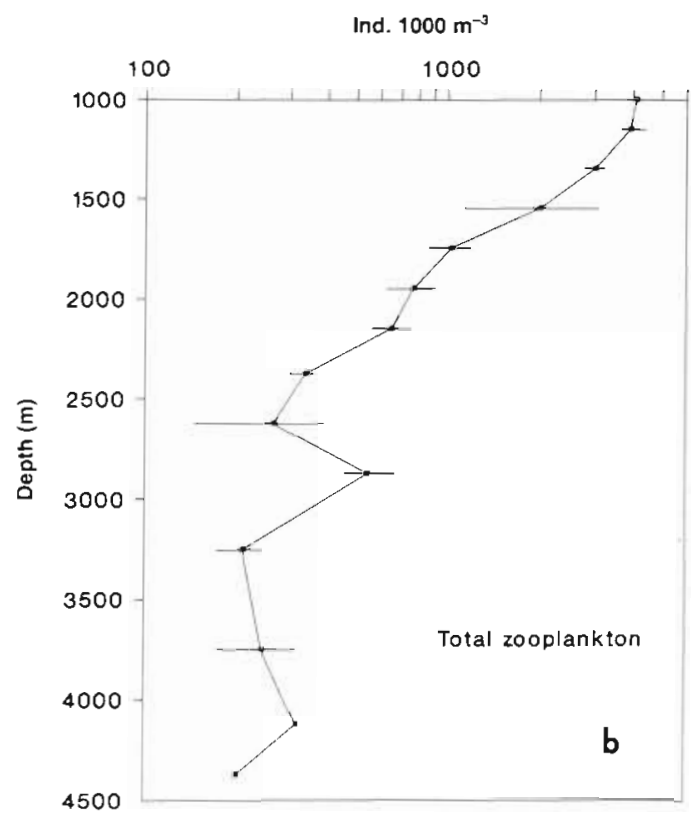

Fig. 2. Vertical distribution of total zooplankton numbers for depths (a) 0-1000 $\mathrm{m}$ during the day and night; and (b) $1000-4500 \mathrm{~m}$, day and night data averaged; horizontal bars represent range of day/night data. (c) Total biomass for depths 0-4500 m. BT: BIOTRANS area; EC: European community station 
Table 3. Standing crops (ind. $\mathrm{m}^{-2}$ ) in the upper 400 to $500 \mathrm{~m}$ of different oceanic areas. TZ: total zooplankton; C: copepoda 1: ind. $<5 \mathrm{~mm}$, without Protozoa; 2: day profiles; 3 : cold-core eddy; 4 : mean value during a longer period

\begin{tabular}{|c|c|c|c|c|c|c|c|}
\hline & \multicolumn{2}{|c|}{$\begin{array}{l}\text { Atlantic BIOTRANS } \\
\text { site (this study) }\end{array}$} & \multirow{2}{*}{$\begin{array}{c}\text { Atlantic } \\
48^{\circ} \mathrm{N}, 21^{\circ} \mathrm{W} \\
\text { (Beckmann et al. 1987) } \\
\text { TZ }\end{array}$} & \multicolumn{2}{|c|}{$\begin{array}{c}\text { Atlantic } \\
46^{\circ} 30^{\prime} \mathrm{N}, 8^{\circ} \mathrm{W} \\
\text { (Colman 1962) }\end{array}$} & \multicolumn{2}{|c|}{$\begin{array}{c}\text { Atlantic } \\
32^{\circ} \mathrm{N}, 64^{\circ} \mathrm{W} \\
\text { (Deevey \& Brooks 1977) }\end{array}$} \\
\hline & $\mathrm{TZ}$ & C & & $\mathrm{TZ}$ & C & C & C \\
\hline \multicolumn{8}{|l|}{ Depth $(\mathrm{m})$} \\
\hline $0-400$ & 17300 & 13960 & $41400-50700$ & - & - & - & - \\
\hline $0-500$ & - & - & - & 55260 & 42280 & 79700 & 12900 \\
\hline $\begin{array}{l}\text { Mesh size } \\
(\mu \mathrm{m})\end{array}$ & 333 & 333 & 300 & 230 & 230 & 202 & 363 \\
\hline Remarks & 1,2 & 1,2 & 2,3 & 2 & 2 & 4 & 4 \\
\hline
\end{tabular}

which is weakly indicated in the artificially composed biomass profile (Fig. 2), fell within the range of the Middle North Atlantic Deep water. This is mixed with water from the Polar Sea which has a higher oxygen and salinity content (see Harvey 1982, Mittelstaedt et al. 1986) and, as a mere speculation, may contain a larger concentration of potential food particles.

\section{A proposed vertical distribution 'model' of zooplankton}

To describe the vertical distribution of zooplankton, many authors used exponential regressions $(\log y=\log$ $a+b x$, where $y=$ concentration and $x=$ depth; Wishner 1980, Angel \& Baker 1982, Scotto di Carlo et al. 1984, Roe 1988, Weikert \& Trinkaus 1990) probably due to the log-linear graphics introduced by Vinogradov (1968). The underlying hypothesis of this analysis is that the regression constant $a$ is an estimate of the productivity at the sea surface over a certain period of time and the regression coefficient $b$ is a measure of the flux of organic material to the depth (Wishner 1980, Angel \& Baker 1982).

As noted by Angel et al. (1982) and also indicated by our profiles, the variability of the zooplankton in the upper $1000 \mathrm{~m}$ is very high and strongly affected by its diurnal migrations, mainly by metridiniids (Pleuromamma spp. and Metridia spp.). Therefore, these data should be disregarded to avoid migration influences. However, in our study the logarithmic decline of zooplankton numbers with depth is not linear below 1000 $m$ (test on linearity: $p<0.001$; Sachs 1978). Also the zooplankton biomass distributions from depths $>1000$ m, published by Vinogradov (1968) for the Pacific and Indian Oceans, and by Angel \& Baker (1982) and Roe (1988) for the NE Atlantic, are not exponential at a closer view. However, these data could not be tested on linearity, because the sample size of the singular profiles is not sufficient for a linearity test. This means that

\section{Total zooplankton}

log Ind. $1000 \mathrm{~m}^{-3}$

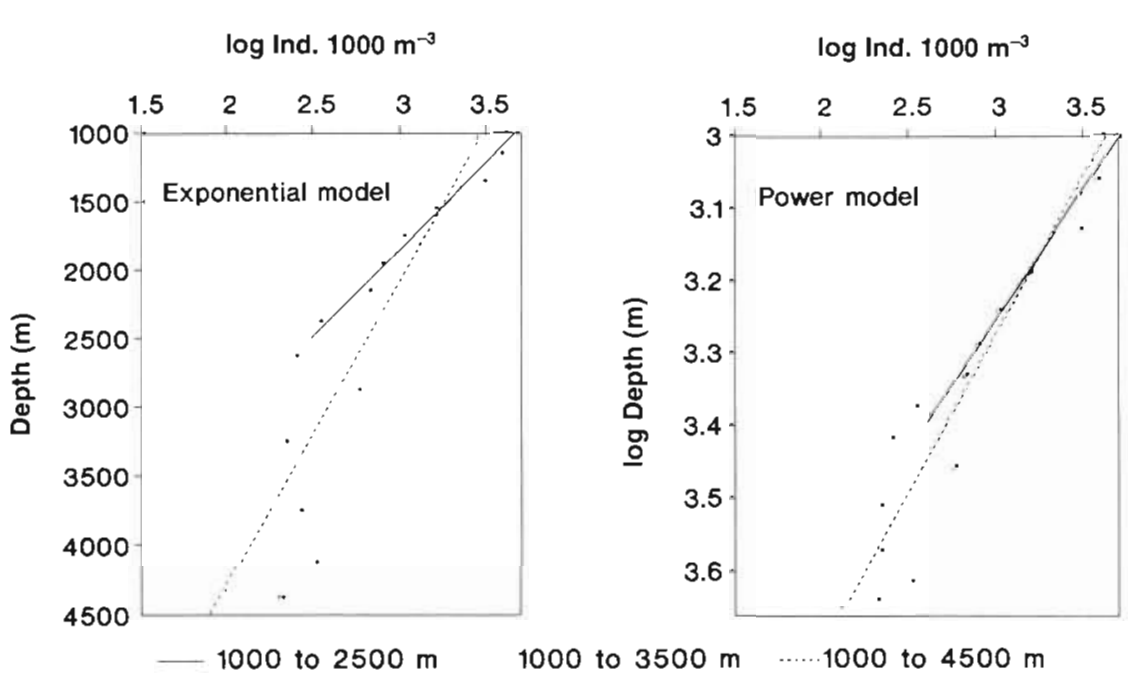

log Ind. $1000 \mathrm{~m}^{-3}$

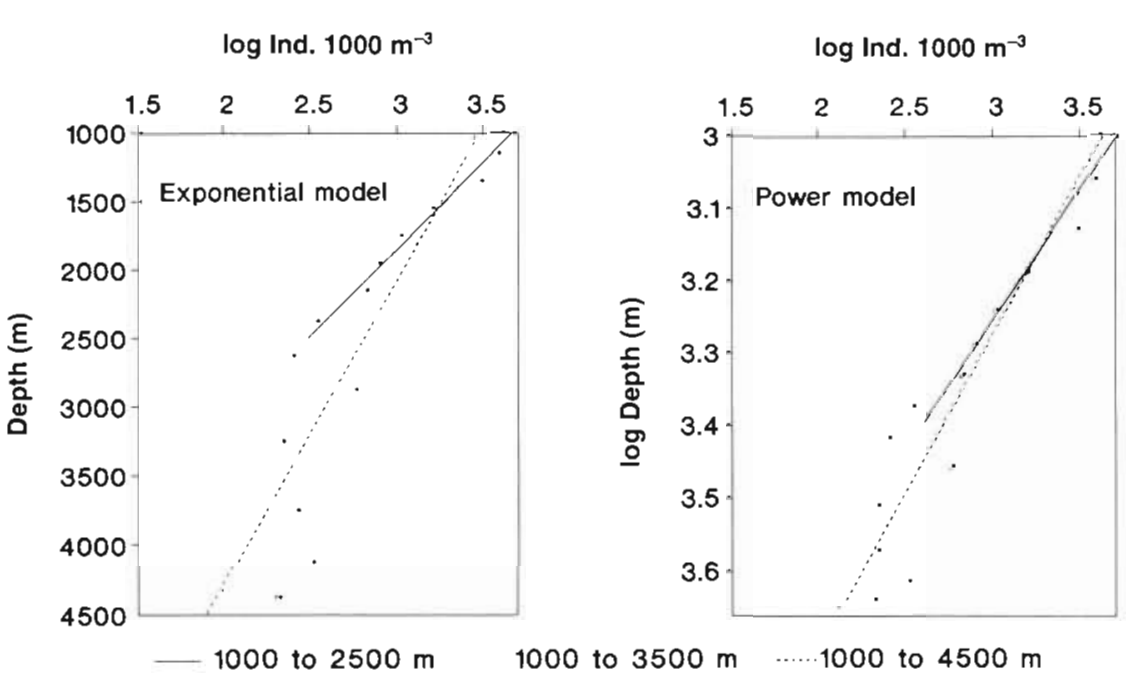

Fig. 3. Regression lines for the profiles of zooplankton numbers obtained from the exponential model (left) and the power model (right) assuming different sampling depths 
Table 4. Regression analysis for the abundance profiles in Fig. 3 (for further details see text). -: depth-related quotient of slopes obtained by dividing the highest by the lowest value

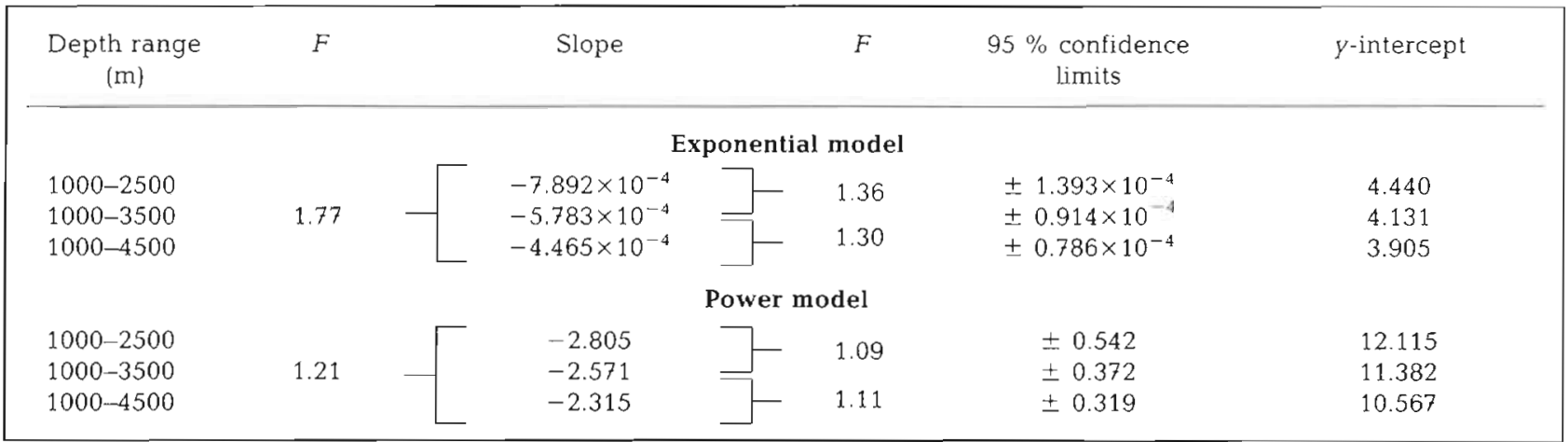

the commonly used exponential regression is not appropriate to describe the decrease of zooplankton with depth. Differences or similarities between regression lines may thus be blurred by using this calculation.

We propose a power regression $(\log y=\log a+b \log$ $x)$ which is in better accordance with the measured points (test on linearity: $p=0.014$ ). This is especially important when results from different sampling depths are compared. Calculating separate regressions for our individual counts assuming arbitrary maximum sampling depths of 2500, 3500 and $4500 \mathrm{~m}$ (Fig. 3), the slopes of the exponential regressions for the respective depths ranges were $-7.892 \times 10^{-4},-5.783 \times 10^{-4}$, and $-4.465 \times 10^{-4}$, but for the power regressions were $-2.805,-2.571$, and -2.315 . Calculating the depthrelated quotients of the slopes for each regression by dividing the highest by the lowest values, the largest quotients were obtained from the exponential regressions (Table 4). This result also holds true for our biomass data (Table 5) and those from previous studies (Vinogradov 1968, Angel \& Baker 1982, Roe 1988). The conclusion is that the regressions of the power 'model' are more similar than those of the exponential 'model' (Fig. 3), and therefore, data from different sampling

Table 5. Regression analysis of bathypelagic biomass profiles assuming different sampling depths (for further details see text) $F$-values calculated as in Table 4

\begin{tabular}{|c|c|c|c|c|c|c|c|}
\hline \multirow{3}{*}{$\begin{array}{l}\text { Data (Source) } \\
\text { NE Atlantic } \\
333 \mu \mathrm{m} \text { mesh size } \\
\text { (This study) }\end{array}$} & \multirow{3}{*}{$\begin{array}{c}\begin{array}{c}\text { Depth range } \\
(\mathrm{m})\end{array} \\
1000-2500 \\
1000-3500 \\
1000-4500\end{array}$} & \multicolumn{2}{|c|}{ Exponential model } & & \multicolumn{3}{|c|}{ Power model } \\
\hline & & Slope & $F$-value & & Slope & $F$-value & \\
\hline & & $\begin{array}{l}-4.089 \times 10^{-4} \\
-3.532 \times 10^{-4} \\
-3.194 \times 10^{-4}\end{array}$ & $\begin{array}{r}-\sqrt{-}-1.16 \\
-\sqrt{-1}-11\end{array}$ & -1.28 & $\begin{array}{l}-1.421 \\
-1.521 \\
-1.605\end{array}$ & $\begin{array}{r}1.07 \\
-1.06\end{array}$ & $\mid-1.13$ \\
\hline $\begin{array}{l}\text { NE Atlantic } \\
320 \text { Mm mesh size } \\
\text { (Roe 1988) }\end{array}$ & $\begin{array}{l}1000-2500 \\
1000-4000 \\
1000-5400\end{array}$ & $\begin{array}{l}-5.843 \times 10^{-4} \\
-4.912 \times 10^{-4} \\
-3.662 \times 10^{-4}\end{array}$ & $\begin{array}{l}=1.19 \\
=1.34\end{array}$ & -1.60 & $\begin{array}{l}-2.020 \\
-2.341 \\
-2.316\end{array}$ & $\begin{array}{r}-1.16 \\
-1.01\end{array}$ & -1.15 \\
\hline $\begin{array}{l}\text { NE Atlantic } \\
330 \text { um mesh size } \\
\text { (Angel \& Baker 1982) }\end{array}$ & $\begin{array}{l}1000-2500 \\
1000-3500 \\
1000-4500\end{array}$ & $\begin{array}{l}-8.822 \times 10^{-4} \\
-5.109 \times 10^{-} \\
-3.539 \times 10^{-4}\end{array}$ & $\begin{array}{l}\square-1.73 \\
=-1.44\end{array}$ & -2.49 & $\begin{array}{l}-3.283 \\
-2.450 \\
-2.050\end{array}$ & $\begin{array}{r}-1.34 \\
-1.20\end{array}$ & -1.60 \\
\hline $\begin{array}{l}\text { NW Pacific } \\
380 \text { um mesh size } \\
\text { (Vinogradov 1968; Table 16) }\end{array}$ & $\begin{array}{l}1000-4000 \\
1000-6000 \\
1000-8000\end{array}$ & $\begin{array}{l}-5.270 \times 10^{-4} \\
-3.662 \times 10^{-4} \\
-3.174 \times 10^{-4}\end{array}$ & $\begin{array}{l}-1.44 \\
=-1.15\end{array}$ & -1.66 & $\begin{array}{l}-2.568 \\
-2.472 \\
-2.511\end{array}$ & $\begin{array}{r}\square-1.04 \\
-1.02\end{array}$ & -1.02 \\
\hline $\begin{array}{l}\text { Tropical Pacific } \\
380 \mu \mathrm{m} \text { mesh size } \\
\text { (Vinogradov 1968; Table 18) }\end{array}$ & $\begin{array}{l}1000-4000 \\
1000-6000 \\
1000-8000\end{array}$ & $\begin{array}{l}-3.815 \times 10^{-4} \\
-2.848 \times 10^{-4} \\
-2.643 \times 10^{-4}\end{array}$ & $\begin{array}{r}\square \\
=-1.34 \\
-1.08\end{array}$ & -1.44 & $\begin{array}{l}-1.992 \\
-1.843 \\
-1.921\end{array}$ & $\begin{array}{l}\square-1.08 \\
=-1.04\end{array}$ & -1.04 \\
\hline $\begin{array}{l}\text { Indian Ocean } \\
380 \mu \text { mesh size } \\
\text { (Vinogradov 1968; Table 20) }\end{array}$ & $\begin{array}{l}1000-2000 \\
1000-2500 \\
1000-4000\end{array}$ & $\begin{array}{l}-7.618 \times 10^{-4} \\
-5.783 \times 10^{-4} \\
-5.095 \times 10^{-4}\end{array}$ & $\begin{array}{l}-1.32 \\
=-1.14\end{array}$ & -1.50 & $\begin{array}{l}-2.766 \\
-2.565 \\
-2.462\end{array}$ & $\begin{array}{r}-108 \\
-1.04\end{array}$ & - 1.12 \\
\hline
\end{tabular}


depths can be compared by statistical methods. Like nearly all approximations, this calculation is not optimal. Nevertheless, it is closer to the real distribution than the previous calculations.

In the following, we apply the power regression to compare our data with those of other authors. Since data for individual numbers from below $1000 \mathrm{~m}$ are scarce, we used biomass data.

Wishner (1980) determined depth-related wet weight biomass from catches at 10 and $100 \mathrm{~m}$ above the sea bottom with a $183 \mu \mathrm{m}$ mesh in different areas of the Atlantic and Pacific Oceans, respectively. Dry weight

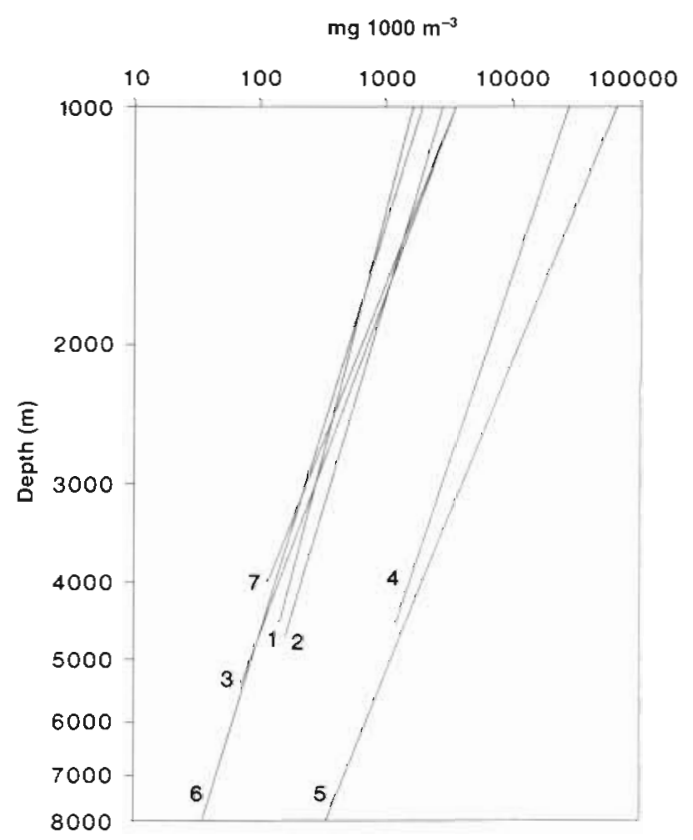

Fig. 4. Regression lines for the profiles of biomass (power function) below $1000 \mathrm{~m}$ from different parts of the world ocean. 1. NE Atlantic (this study); 2: Atlantic/Pacific (Wishner 1980); 3: NE Atlantic (Roe 1988); 4: NE Atlantic (Angel \& Baker 1982); 5: NW Pacific (Vinogradov 1968, Table 16); 6: Tropical Pacific (Vinogradov 1968, Table 18); 7: Indian Ocean (Vinogradov 1968, Table 20) data (mesh size $320 \mu \mathrm{m}$ ) from the NE Atlantic $\left(31^{\circ} 17^{\prime} \mathrm{N}\right.$, $25^{\circ} 24^{\prime} \mathrm{W}$ ) by Roe (1988) were converted (conversion factor, $1: 5$ ) into wet weights after Cushing et al. (1958). Angel \& Baker (1982) used displacement volumes for their data from the NE Atlantic $\left(42^{\circ} \mathrm{N}, 17^{\circ} \mathrm{W}\right)$ taken with a $330 \mu \mathrm{m}$ mesh. These values were converted (conversion factor, $1: 0.73$ ) into wet weights after Wiebe et al. (1975). Wet weight data (380 $\mu \mathrm{m}$ mesh) from the NW Pacific, the tropical Pacific and the Indian Ocean were taken from Vinogradov (1968).

Fig. 4 shows the regression lines, and Table 6 the corresponding values. The regression coefficients of the slopes are between 1.6 and 2.5. Although they seem to show a high similarity, especially between Lines 1 (our data), 2 (Wishner 1980), 3 (Roe 1988), 6 (Vinogradov 1968; Tropical Pacific) and 7 (Vinogradov 1968; Indian Ocean), significant differences exist between the regressions ( $\mathrm{p}=0.045$, $\mathrm{df}=6,194$, analysis of covariance: Sokal \& Rohlf 1969, Weber 1986). An a posteriori test (Table 7) (Sokal \& Rohlf 1969) shows no significant difference between the slopes of the lines. This means that the processes of material flux seem to be similar in most bathypelagic systems of the open ocean, as discussed by Wishner (1980) and Roe (1988) who applied the exponential regression. The concurrence of the slopes exists despite the use of different mesh sizes, i.e. different size groups of zooplankton were compared. However, there are significant differences between the $y$-intercepts of Group A [Lines 4 (Angel \& Baker 1982; NE Atlantic) and 5 (Vinogradov 1968; NW Pacific)] and Group B (Lines 1, 2, 3, 6 \& 7), but no differences exist within the 2 groups. These differences may result from either a higher surface productivity in some ocean areas or differences in methods of sampling and evaluation of material.

Although the power regression was found empirically, we will propose biological interpretations which may have led to less of a decrease in deep-living zooplankton at depths below $2500 \mathrm{~m}$ as compared to the strong exponential decrease seen at depths above $2500 \mathrm{~m}$. Similar profiles were presented from the NE

Table 6. Linear regression coefficients for biomass as a function of depth below $1000 \mathrm{~m}$ in the open oceans, calculated by the power function $(\log y=\log a+b \log x)$. CL: confidence limits of the regression coefficients. 'No.' corresponds to profile no, in Fig. 4

\begin{tabular}{|c|c|c|c|c|c|}
\hline No. & Area & $y$-intercept & Slope & $95 \% \mathrm{CL}$ & $r^{2}$ \\
\hline 1 & NE Atlantic & 8.03 & -1.605 & \pm 0.429 & 0.640 \\
\hline 2 & Atlantic Pacific & 8.99 & -1.847 & \pm 0.568 & 0.807 \\
\hline 3 & NE Atlantic & 10.50 & -2.316 & \pm 0.576 & 0.853 \\
\hline 4 & NE Atlantic & 10.58 & -2.050 & \pm 0.712 & 0.731 \\
\hline 5 & NW Pacific & 12.34 & -2.511 & \pm 0.244 & 0.871 \\
\hline 6 & Tropical Pacific & 9.05 & -1.921 & \pm 0.603 & 0.509 \\
\hline 7 & Indian Ocean & 10.94 & -2.462 & \pm 0.625 & 0.692 \\
\hline
\end{tabular}


Table 7. A posteriori test of the regressions for regional biomasses after Sokal \& Rohlf (1969). The sums of squares (SQ) of the slopes are presented in the upper right triangle, and the SQ of the $y$-intercepts in the lower left triangle. SQcrit: 0.05 $=0.997$. Group no. corresponds to no. and source in Fig. 4. Bold values denote significant differences

\begin{tabular}{|c|c|c|c|c|c|c|c|}
\hline Group & 1 & 2 & 3 & 4 & 5 & 6 & 7 \\
\hline \multicolumn{8}{|c|}{ SQ slope } \\
\hline 1 & - & 0.023 & 0.259 & 0.073 & 0.725 & 0.072 & 0.287 \\
\hline 2 & 0.143 & - & 0.079 & 0.012 & 0.224 & 0.002 & 0.112 \\
\hline 3 & 0.064 & 0.074 & - & 0.024 & 0.027 & 0.094 & 0.008 \\
\hline 4 & 10.658 & 5.537 & 7.194 & - & 0.098 & 0.007 & 0.047 \\
\hline 5 & 27.569 & 12.684 & 16.622 & 0.555 & - & 0.417 & 0.001 \\
\hline 6 & 0.013 & 0.380 & 0.130 & 13.717 & 40.957 & - & 0.129 \\
\hline 7 & 0.082 & 0.147 & 0.030 & 10.518 & 29.294 & 0.127 & - \\
\hline \multicolumn{8}{|c|}{ SQ $y$-intercept } \\
\hline
\end{tabular}

Atlantic by Angel \& Baker (1982), who however did not take notice of this pattern. Not unexpected, the bathymetric distribution of zooplankton does not appear as a mere function of depth, but is likely influenced by additional factors such as faunal changes, interactions between organisms and, last but not least, food supply.

The species-specific analysis, which is still in progress, revealed that at about $2000 \mathrm{~m}$ a number of new species occurred among the copepod fauna, such as Benthomisophria spp., Hyalopontius spp., Foxtonia barbatula Hülsemann \& Grice 1963 and some unidentified calanoids. Whether or not this faunal alteration is symptomatic, its relation to trophic interactions is still to be investigated. Since the concentration of organisms declines with increasing depth, predator-prey relationships are believed to be secondary to an omnivorous/ detritivorous lifestyle (Vinogradov \& Tseitlin 1983) because of energetical and/or behavioural reasons (see Childress et al. 1990 for discussion of this issue).

The source of food supply to the deep sea is almost exclusively from the autotrophic surface regime. Data provided by sediment traps assumed an exponential decrease of sinking organic matter with depth (e.g. Honjo 1980, Berger et al. 1988). However, resuspension and upward flux can be seen up to $2000 \mathrm{~m}$ above the seabed and are induced by physical and biological agents [see discussion of Angel (1990) and literature cited therein]. The intensity and constancy of the upward flux is little understood. Without a doubt, however, a pathway from great depths towards the ocean surface exists for a variety of organisms and their ontogenetic stages which allows edible material to be recycled by their own bodies and their gut contents (Bouchet \& Waren 1986, Roe et al. 1990). Smith et al. (1989) used inverted sediment traps at 2 bathyal stations in the North Pacific and found an upward flux of particles and eggs which was two-thirds of the concurrently measured downward flux, although entrapped larvae of deep-sea euphausiids were omitted from the calculation. At some times and latitudes, upward fluxes by the seasonal release of planktonic larvae of benthic opportunists can be considered to be important (Tyler 1988); dietary studies of surface-feeding birds in the Southern Ocean revealed that up to $70 \%$ of the food consisted of deep-sea benthopelagic animals (Ridoux \& Coic 1988).

As exemplified by one profile of detrital material (phytodetritus) from our May data, there is a significant coherence (rank correlation analysis $p=0.001$ ) between phytodetritus and zooplankton (Fig. 5). We cannot appraise how quantitatively the material was caught by nets; however, it is a first presentation of the distribution of large-sized flocculent material at bathyal depths. It has been suggested that old phytodetritus

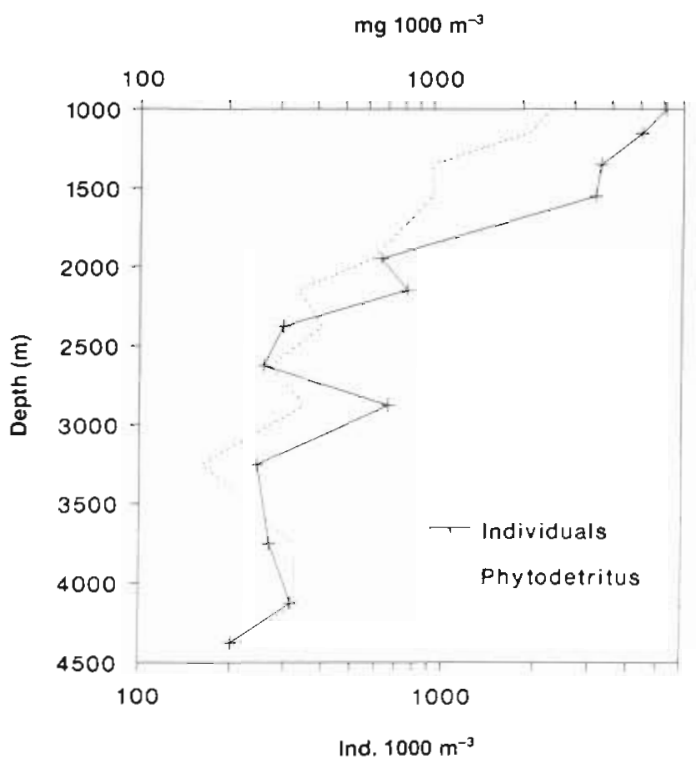

Fig. 5. Vertical distribution of phytodetritus (mg $\left.1000 \mathrm{~m}^{-3}\right)$ and zooplankton (ind. $1000 \mathrm{~m}^{-3}$ ) below $1000 \mathrm{~m}$ during May 1988 
is more easily subjected to resuspension than freshly settled material (Angel 1990). The respective microscopic study of our material and cytochemical analyses is in process.

In conclusion, the tendency of 'arrested' zooplankton numbers and biomass with depth commencing at about $2000 \mathrm{~m}$ above the sea floor seems to be a reliable and biologically plausible feature. Theoretically, the upward flux of dead and alive particles compensates for the downward gradient of individuals and biomass until losses by predation will predominate with increasing distance to the seabed. Due to the better adaptation, which describes the obviously natural distribution pattern more exactly, the power regression should be superior to an exponential one.

Acknowledgements. We are grateful to all those who were involved in taking the samples, especially Werner Beckmann and the officers and crew members of the RV 'Meteor' We thank Dr Bernd Christiansen for critical comments on the statistics and Katrin Lampe for sorting and weighing the phytodetritus. Dr Eric J. Foell kindly improved the English text. Some anonymous reviewers made helpful comments to the manuscript. The investigations were funded by the Ministry of Science and Technology of the Federal Republic of Germany (MFU 0544/9).

\section{LITERATURE CITED}

Angel, M. V. (1979). Studies on Atlantic halocyprid ostracods: their vertical distributions and community structure in the central gyre region along $30^{\circ} \mathrm{N}$ from off Africa to Bermuda. Prog. Oceanogr. 8: 3-124

Angel, M. $V$ (1990). Life in the benthic boundary layer connections to the mid-water and sea floor Phil. Trans. R. Soc. Lond. Ser A. 331. 15-28

Angel, M. V., Baker, A. de C. (1982). Vertical distribution of the standing crop of plankton and micronekton at three stations in the Northeast Atlantic. Biol. Oceanogr 2: 1-30

Angel, M. V., Hargreaves, P., Kirkpatrick, P., Domanski, P. (1982). Low variability in planktonic and micronektonic populations at $1,000 \mathrm{~m}$ depth in the vicinity of $42^{\circ} \mathrm{N}, 17^{\circ} \mathrm{W}$; evidence against diel migratory behavior in the majority of species. Biol. Oceanogr 1:287-319

Barnes, H., Tranter, D. J. (1965). A statistical examination of the catches, numbers and biomass taken by three commonly used plankton nets. Aust. J. mar. Freshwat. Res. 16: $1-30$

Beckmann, W. (1988). The zooplankton community in the deep bathyal and abyssal zones of the eastern North Atlantic. Preliminary results and data lists from MOCNESS hauls during cruise 08 of the RV 'POLARSTERN' Ber. Polarforsch. 42: 1-57

Beckmann, W., Auras, A., Hemleben, C. (1987). Cyclonic coldcore eddy in the eastern North Atlantic. III. Zooplankton. Mar Ecol. Prog. Ser. 39: 65-73

Berger, W H., Fischer, K., Lai, C., Wu, G. (1988). Ocean carbon flux: global maps of primary production and export production. In: Aegigian, C. R. (ed.) Biogeochemical cycling and fluxes between the deep euphotic zone and other oceanic realms. NOAA National Undersea Research Program, Research Report 88-1: 131-176
Berner, L. D. (1957). Studies on the Thaliacea of the temperate northeast Pacific Ocean. Ph.D. thesis, Scripps Institution of Oceanography, University of California, San Diego

Berner, L. D. (1967). Distributional atlas of Thaliacea in the California Current region. Calif. coop. ocean. Fish. Invest. Atlas 8: 1-322

Billett, D. S. M., Lampitt, R. S., Rice, A. L., Mantoura, R. F. C. (1983). Seasonal sedimentation of phytoplankton to the deep-sea benthos. Nature, Lond. 302: 520-522

Böttger, R. (1987). The vertical distribution of micro- and small mesozooplankton in the Central Red Sea. Biol. Oceanogr 4: 383-402

Bouchet, P., Waren, A. (1986). Revision of northeast Atlantic bathyal and abyssal Aclididae, Eulimidae, Epitonidae (Mollusca, Gastropoda). Boll. Malacologica 2: 297-576

Childress, J. J., Cowles, D. L., Favuzzi, J. A., Mickel, T J. (1990). Metabolic rates of benthic deep-sea decapod crustaceans decline with increasing depth primarily due to the decline in temperature. Deep Sea Res. 37. 929-949

Colman, J. S. (1962). A note on deep plankton in the Bay of Biscay. Rapp. P.-v. Réun. Cons. perm. int. Explor. Mer 153: $207-210$

Cushing, D. H., Humphrey, G. F., Banse, K., Laevastu, T (1958). Report of the Committee on Terms and Equivalents. Rapp. P.-v. Réun. Cons. perm. int. Explor. Mer 144: $15-16$

Deevey, G. B., Brooks, A. L. (1977). Copepods of the Sargasso Sea off Bermuda: species composition, and vertical and seasonal distribution between the surface and $2000 \mathrm{~m}$. Bull. mar Sci. 27: 256-291

Deibel, D. (1982), Laboratory-measured grazing and ingestion rates of the salp. Thalia democratica Forskal, and the doliolid, Dolioletta gegenbauri Uljanin (Tunicata, Thaliacea). J. Plankton Res. 4: 189-201

Harbison, G. R., Gilmer, R. W. (1976). The feeding rates of the pelagic tunicate Pegea confederata and two other salps. Limnol. Oceanogi 21:517-528

Harvey, J. (1982). $\Theta-S$ relationships and water masses in the eastern North Atlantic. Deep Sea Res. 29: 1021-1033

Honjo, S. (1980). Material fluxes and modes of sedimentation in the mesopelagic and bathypelagic zones. J. mar Res. 38: 53-97

Longhurst, A. R., Bedo, A., Harrison, W G., Head, E. J. H., Horne, E. P., Irwin, B., Morales, C. (1989). NFLUX: a test of vertical nitrogen flux by diel migrant biota. Deep Sea Res. 36: $1705-1719$

Mittelstaedt, E., Bock, M., Bork, I., Klein, H., Nies, H., Schauer, U. (1986). Ausbreitungsbedingungen für Stoffe in großen Ozeantiefen. Nordostatlantisches Monitoring Programm. Deutsches Hydrographisches Institut, Hamburg

Pfannkuche, O., Beckmann, W., Christiansen, B., Lochte, K., Rheinheimer, G., Thiel, H., Weikert, H. (1990). BIOTRANS - Biologischer Vertikaltransport und Energiehaushalt in der bodennahen Wasserschicht der Tiefsee. Berichte aus dem Zentrum für Meeres- und Klimaforschung der Universität Hamburg 10: 1-159

Pfannkuche, O., Lochte, K., Thiel, H. (1988). Sedimentation of spring phytodetritus to the deep-sea floor. EOS 69 (44): 1117 (Abstract)

Rice, A. L., Billett, D. S. M., Fry, J., John, A. W. G., Lampitt, R. S., Mantoura, R. F. C., Morris, R. J. (1986). Seasonal deposition of phytodetritus to the deep-sea floor. Proc. R. Soc. Edinb. 88B: 265-279

Ridoux, V., Coic, D. (1988). How can surface-feeding seabirds prey upon deep-sea organisms? Fifth Deep-Sea Biology Symposium. Brest, p. 173 (Abstracts) 
Roe, H. S. J. (1988). Midwater biomass profiles over the Madeira Abyssal Plain and the contribution of copepods. Hydrobiologia 167/168: 169-181

Roe, H. S. J., Billett, D. S. M., Lampitt, R. S. (1990): Benthic/ midwater interactions on the Madeira Abyssal Plain; evidence for biological transport pathways. Prog. Oceanogr. $24: 127-140$

Sachs, L. (1978). Angewandte Statistik, 5th edn. SpringerVerlag, Berlin

Scotto di Carlo, B., Ianora, A., Fresi, E., Hure, J. (1984) Vertical zonation patterns for Mediterranean copepods from the surface to $3000 \mathrm{~m}$ at a fixed station in the Tyrrhenian Sea. J. Plankton Res. 6: 1031-1056

Silver, M. W., Bruland, K. W (1981). Differential feeding and fecal pellet composition of salps and pteropods, and the possible origin of deep-water flora and olive-green 'cells'. Mar. Biol. 62: 263-273

Smith, K. L., Williams, P. M., Druffel, E. R. M. (1989). Upward fluxes of particulate organic matter in the deep North Pacific. Nature, Lond. 337: 724-726

Sokal, R. R., Rohlf, F. J. (1969). Biometry. W.H. Freeman and Company, San Francisco

Steedman, H. F. (1976). General and applied data on formaldehyde fixation and preservation of marine zooplankton In: Steedman, H. F. (ed.) Zooplankton fixation and preservation. UNESCO Monographs on Oceanographic Methodology 4. UNESCO Press, Paris, p. 103-154

Stienen, C., Beckmann, W., Zeitzschel, B. (1988). Patterns of a spring mass-sedimentation. EOS 69(44): 1117 (Abstract)

Thiel, H., Pfannkuche, O., Schriever, G., Lochte, K., Gooday, A. J., Hemleben, C., Mantoura, R. F. G., Turley, C. M., Patching, J. W. Riemann, F. (1988/1989). Phytodetritus on the deep-sea floor in a central oceanic region of the Northeast Atlantic. Biol. Oceanogr. 6: 203-239

Tranter, D. J. (1962). Zooplankton abundance in Australian waters. Aust. J. mar. Freshwat. Res. 13: 106-142

Tyler, P. A. (1988). Seasonality in the deep-sea. Oceanogr mar. Biol. A. Rev. 26: 227-258

The article was submitted to the editor
Vinogradov, M. E. (1968). Vertical distribution of the Oceanic zooplankton. Academy of Science of the U.S.S.R., Institut of Oceanography. In Russian, translated by Israel Program for Scientific Translation Ltd., Keter Press, Jerusalem, 1970

Vinogradov, M. E., Tseitlin, V. B. (1983). Deep-sea pelagic domain (aspects of bioenergetics). In: Rowe, $G$. $T$ (ed.) Deep-sea biology. The sea, Vol. 8. John Wiley, New York, p. $123-165$

Weber, E. (1986). Grundriß der biologischen Statistik, 9th edn. Gustav Fischer Verlag, Stuttgart

Weikert, H. (1977). Copepod carcasses in the upwelling region south of Cap Blanc, NW Africa. Mar. Biol. 42: 351-357

Weikert, H. (1982). The vertical distribution of zooplankton in relation to habitat zones in the area of the Atlantis II Deep Central Red Sea. Mar. Ecol. Prog. Ser. 8: 129-143

Weikert, H. (1990). A proposed vertical distribution pattern of micronekton in the deep Levantine Sea, Eastern Mediterranean, and its applicability to the Red Sea. Bull. Inst. océanogr. Monaco, $n^{\circ}$ spécial 7 : 39-50

Weikert, H., John, H.-C. (1981). Experiences with a modified Bé multiple opening-closing plankton net. J. Plankton Res. 3: $167-176$

Weikert, H., Trinkaus, S. (1990). Vertical mesozooplankton abundance and distribution in the deep Eastern Mediterranean Sea SE of Crete. J. Plankton Res. 12: 601-628

Wheeler, E. H. (1967). Copepod detritus in the deep-sea. Limnol. Oceanogr. 12: 697-702

Wiborg, K. F. (1951). The whirling vessel, an apparatus for the fractioning of plankton samples. Fisk.Dir. Skr.9: 1-16

Wiebe, P. H., Boyd, S. H., Cox, J. L. (1975). Relationships between zooplankton displacement volume, wet weight, dry weight, and carbon. Fish. BulI. U.S. 73: 777-786

Wiebe, P. H., Morton, A. W., Bradley, A. M., Backus, R. H., Craddock, J. E., Barber, V., Cowles, T. J., Flierl, G. R. (1985). New developments in the MOCNESS, an apparatus for sampling zooplankton and micronekton. Mar. Biol. 87; 313-323

Wishner, K. F. (1980). The biomass of the deep-sea benthopelagic plankton. Deep Sea Res. 27: 203-216

Manuscript first received: March 6, 1992

Revised version accepted: August 3, 1992 